\title{
UMA PALAVRA DE AGRADECIMENTO
}

Decidiu em boa hora a direç̧ão da revista Gestão $e$ Desenvolvimento promover a publicação de um número de homenagem ao Prof. Doutor António Ribeiro Gomes que, durante tantos anos, a dirigiu. É um acto de justiça que honra também a actual direcção da revista, a que a Reitoria da Universidade não quer deixar de se associar.

Desde logo, e antes de mais, pela figura académica do Prof. Ribeiro Gomes, e pelo muito que a Universidade Católica lhe deve, por toda a sua dedicada colaboração ao Centro Regional das Beiras em Viseu.

O Prof. Ribeiro Gomes foi, durante três mandatos consecutivos, entre Junho de 1993 e Setembro de 2005, Director do Instituto Universitário de Desenvolvimento e Promoção Social (IUDPS), coordenando simultaneamente, neste mesmo período, a licenciatura em matemática da Escola Superior de Ciências e Tecnologia do Centro Regional das Beiras da UCP. Nestes cargos, empenhou-se muito particularmente na elaboração do projecto de desenvolvimento do Centro Regional e de criação de uma nova Faculdade, projecto esse que ficou comprometido pela preferência governamental em apostar antes na criação de uma Universidade pública em Viseu, em detrimento do desenvolvimento da Universidade Católica. Tudo fez para que Viseu pudesse dispor de uma Universidade - a Universidade Católica - ao nível das necessidades do seu desenvolvimento regional. 
Mas para além disso, o Prof. Ribeiro Gomes empenhou-se, desde a primeira hora, na promoção de uma cultura universitária nas unidades onde actuou e que dirigiu, designadamente com o fomento da investigação científica e da publicação dos seus resultados, como o atestam os muitos números desta revista, que dirigiu. Por este facto poderemos dizer com propriedade que o Prof. Ribeiro Gomes tinha da academia uma visão verdadeiramente universitária, pois dava a primazia à criação do conhecimento e à investigação científica.

O seu exemplo de dedicação ao ensino e de valorização da investigação deve pois ser recordado e agradecido pela Universidade Católica e muito especialmente pela revista que dirigiu, a que pessoalmente me associo.

MANUEL BRAGA DA CRUZ

* Reitor da Universidade Católica Portuguesa 